\title{
Helicobacter muridarum sp. nov., a Microaerophilic Helical Bacterium with a Novel Ultrastructure Isolated from the Intestinal Mucosa of Rodents
}

\author{
A. LEE,${ }^{1 *}$ M. W. PHILLIPS, ${ }^{1}$ J. L. O'ROURKE ${ }^{1}$ B. J. PASTER, ${ }^{2}$ F. E. DEWHIRST, ${ }^{2}$ G. J. FRASER, ${ }^{2}$ \\ J. G. FOX, ${ }^{3}$ L. I. SLY, ${ }^{4}$ P. J. ROMANIUK, ${ }^{5}$ T. J. TRUST, ${ }^{5}$ AND S. KOUPRACH ${ }^{6}$ \\ School of Microbiology and Immunology ${ }^{1}$ and Electron Microscopy Unit, ${ }^{6}$ University of New South Wales, Sydney, \\ New South Wales, Australia 2033; Forsyth Dental Center, Boston, Massachusetts $02115^{2}$; Massachusetts \\ Institute of Technology, Cambridge, Massachusetts $02139^{3}$; Department of Microbiology, University \\ of Queensland, St. Lucia, Queensland, Australia 40674; and Department of Biochemistry and \\ Microbiology, University of Victoria, Victoria, British Columbia, Canada V8W $2 \mathrm{Y}^{5}$
}

\begin{abstract}
Helical organisms with novel ultrastructural characteristics were isolated from the intestinal mucosa of rats and mice. These bacteria were characterized by the presence of 9 to 11 periplasmic fibers which appeared as concentric helical ridges on the surface of each cell. The cells were motile with a rapid corkscrewlike motion and had bipolar tufts of 10 to 14 sheathed flagella. The bacteria were microaerophilic, nutritionally fastidious, and physiologically similar to Helicobacter species and Wolinella succinogenes but could be differentiated from these organisms by their unique cellular ultrastructure. Using $16 \mathrm{~S}$ rRNA sequencing, we found that strain ST1 ${ }^{\mathrm{T}}$ ( $\mathrm{T}=$ type strain) was related to previously described Helicobacter species, "Flexispira rappini," and W. succinogenes. The closest relatives of strain ST1" were Helicobacter mustelae and " $F$. rappini" (average similarity value, $96 \%)$. On the basis of phylogenetic data, strain $\operatorname{ST1}^{\mathrm{T}}\left(=\right.$ ATCC $\left.^{49282^{T}}\right)$ represents a new species of the genus Helicobacter, for which we propose the name Helicobacter muridarum.
\end{abstract}

Bacteria with a variety of spiral morphologies are common inhabitants of the gastrointestinal tracts of both humans and animals $(8-10,20,24-26,30,34,39)$. Several of these spiral bacteria are helically coiled and possess bipolar tufts of flagella and concentric ridges that are due to periplasmic fibers that run the length of each cell. They have been seen in a variety of gastrointestinal preparations, including ceca (8) and ilea of rats (34), colons of mice (39), and gastric mucosa (26) and fundic glands of dogs and cats (20). Recently, organisms with a similar morphology have been implicated in ovine abortions $(5,21)$ and in intestinal diseases in animals and humans $(1,37)$.

Much of the recent work on spiral bacteria has concentrated on Helicobacter pylori and other Campylobacter-like organisms because of the postulated association of these bacteria with human gastrointestinal disease $(6,18,28,29)$. The taxonomy of this group of organisms is now being clarified. Recent phylogenetic work has resulted in the creation of the genus Helicobacter, and new species of this genus are rapidly being recognized $(14,17,32,33,36,40$, 43). Although three of the gastric helicobacters are very similar physiologically and show high degrees of similarity $(96 \%)$ in their $16 \mathrm{~S}$ rRNA sequences, these bacteria have very different morphologies $(19,24,31)$. $H$. pylori is a relatively short organism with one or two turns in its spiral body, while Helicobacter musteleae is a short, slightly curved, rodshaped organism with an unusual flagellum configuration. In contrast, Helicobacter felis is 5 to $7 \mu \mathrm{m}$ long and has a tightly spiralled body with five or six turns; it is entwined with a distinctive series of periplasmic fibers.

The distinctive periplasmic fibers are not new to us because 10 years ago we observed similar structures on a bacterium isolated from a rat ileum (34). The same organism

* Corresponding author. has been described previously in the elegant electron microscopic studies of Erlandsen and Chase, who observed spiral microorganisms routinely in the crypts of Lieberkühn in rat small intestines and within the digestive vacuoles of Paneth cells (11). While the natural habitat of this organism is the lower bowel, we have occasionally observed it in the stomachs of normal mice (19a). Thus, we thought that it was possible that this organism is another helicobacter. This possibility was supported by the results obtained with a genus-specific Helicobacter DNA probe, which indicated that the organism is indeed another member of the genus Helicobacter (16). In this paper we provide data which support this hypothesis and describe the unique ultrastructure of this bacterium.

\section{MATERIALS AND METHODS}

Bacterial strains and culture conditions. Strains $S T 1^{\mathrm{T}}(\mathrm{T}=$ type strain) and ST2 were isolated from the intestinal mucosa of rodents by Phillips and Lee (34). Other strains were isolated from rat (strain ST4) and from individual mice (strains ST3 and ST5) by using similar methods. Briefly, mucosal scrapings from rodent ileal and cecal tissue were streaked onto moist lysed blood agar (blood agar base no. 2; Oxoid, Basingstoke, England) supplemented with 5\% horse blood and antibiotics $(10 \mu \mathrm{g}$ of vancomycin per $\mathrm{ml}, 2.5 \mu \mathrm{g}$ of polymyxin B per $\mathrm{ml}, 5 \mu \mathrm{g}$ of trimethoprim per $\mathrm{ml}$, and $2 \mu \mathrm{g}$ of amphotericin per $\mathrm{ml}$ ). The plates were incubated under microaerophilic conditions at $37^{\circ} \mathrm{C}$ for 4 to 6 days.

Ultrastructure and phylogeny studies. All strains were stained with $2 \%$ phosphotungstic acid and examined with a Hitachi model $\mathrm{H} 7000$ transmission electron microscope to determine their morphology. The cell walls were disrupted by resuspending cultures in a nonionic detergent for $10 \mathrm{~min}$ before they were prepared for transmission electron microscopy. The detergent used was Teepol (Shell Chemicals, 


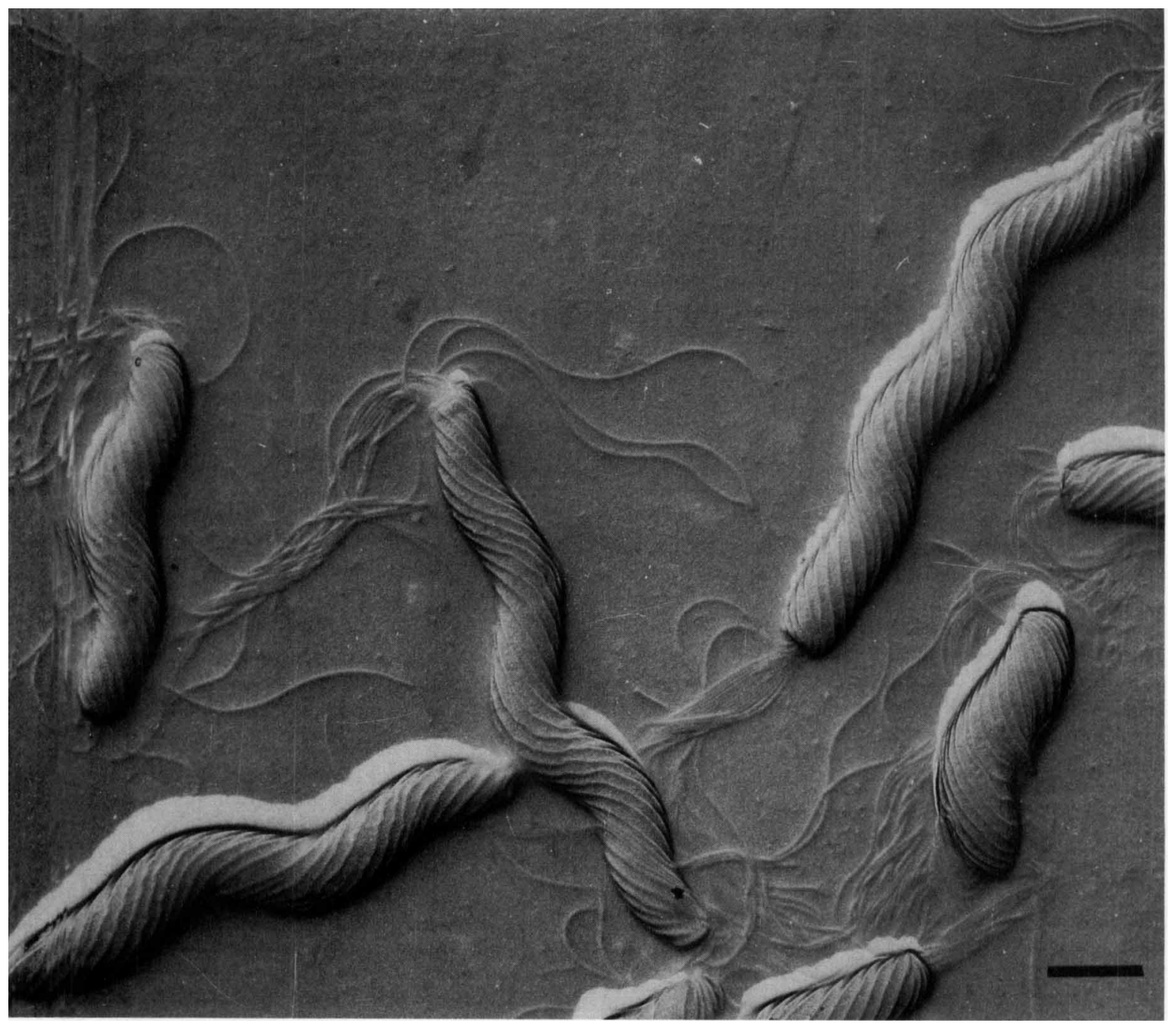

FIG. 1. Freeze-dried preparation of $H$. muridarum sp. nov. showing characteristic $\mathrm{S}$ shape, tufts of bipolar flagella, and periplasmic fibers. Bar $=1 \mu \mathrm{m}$.

Sydney, Australia) at a concentration of $0.2 \%$. Freeze-dried and freeze-fractured preparations of strain $\mathrm{ST}^{\mathrm{T}}$ were prepared as previously described (24).

Biochemical characterization, tests for susceptibility to antimicrobial agents, and 16S rRNA sequencing and analysis were performed as previously described (33). Dendograms were constructed by using the neighbour joining method of Saitou and Nei (38).

DNA base composition. DNA was extracted by using the method of Marmur (27) except that we added two protease treatments, one after lysis by sodium lauryl sulfate and one after the RNase step (2). The $G+C$ values were determined by the $T_{\mathrm{i}}$ method of Sly et al. (41), using a model 2600 microprocessor-controlled spectrophotometer (Gilford Instruments, Oberlin, Ohio) fitted with a thermal programmer.

GenBank accession number. The sequence for Helicobacter muridarum $\mathrm{ST}_{1}^{\mathrm{T}}$ is available for electronic retrieval from GenBank under accession number M80205.

\section{RESULTS}

Isolation and growth characteristics. The helical bacteria designated strains ST1 ${ }^{\mathrm{T}}$, ST2, ST3, ST4, and ST5 grew as fine, spreading films on lysed blood agar plates that were incubated under microaerophilic conditions for 2 to 3 days. It was important to use fresh, moist plates and to incubate them with their lids uppermost for the isolation and cultivation of these bacteria. The optimum growth conditions for these organisms have been described previously (34).

Morphology. The bacteria were helical, gram negative, and motile with a rapid corkscrewlike motion. The cells were 3.5 to $5 \mu \mathrm{m}$ long and 0.5 to $0.6 \mu \mathrm{m}$ wide with two to three spiral turns (Fig. 1).

Ultrastructure. Previous studies (34) of strains $\mathrm{STI}^{\mathrm{T}}$ and ST2 revealed that these organisms have a novel morphology and ultrastructure. They are characterized by the presence of 9 to 11 periplasmic fibers that are coiled around a helical protoplasmic cylinder and by the presence of bipolar tufts of sheathed flagella. Further study elucidated the structure of these features. The detailed ultrastructural analysis described below was performed by using strains $\mathrm{ST} 1^{\mathrm{T}}$ and $\mathrm{ST} 2$; the other strains were examined for characteristic morphological features (i.e., multiple polar flagella and periplasmic fibers). 


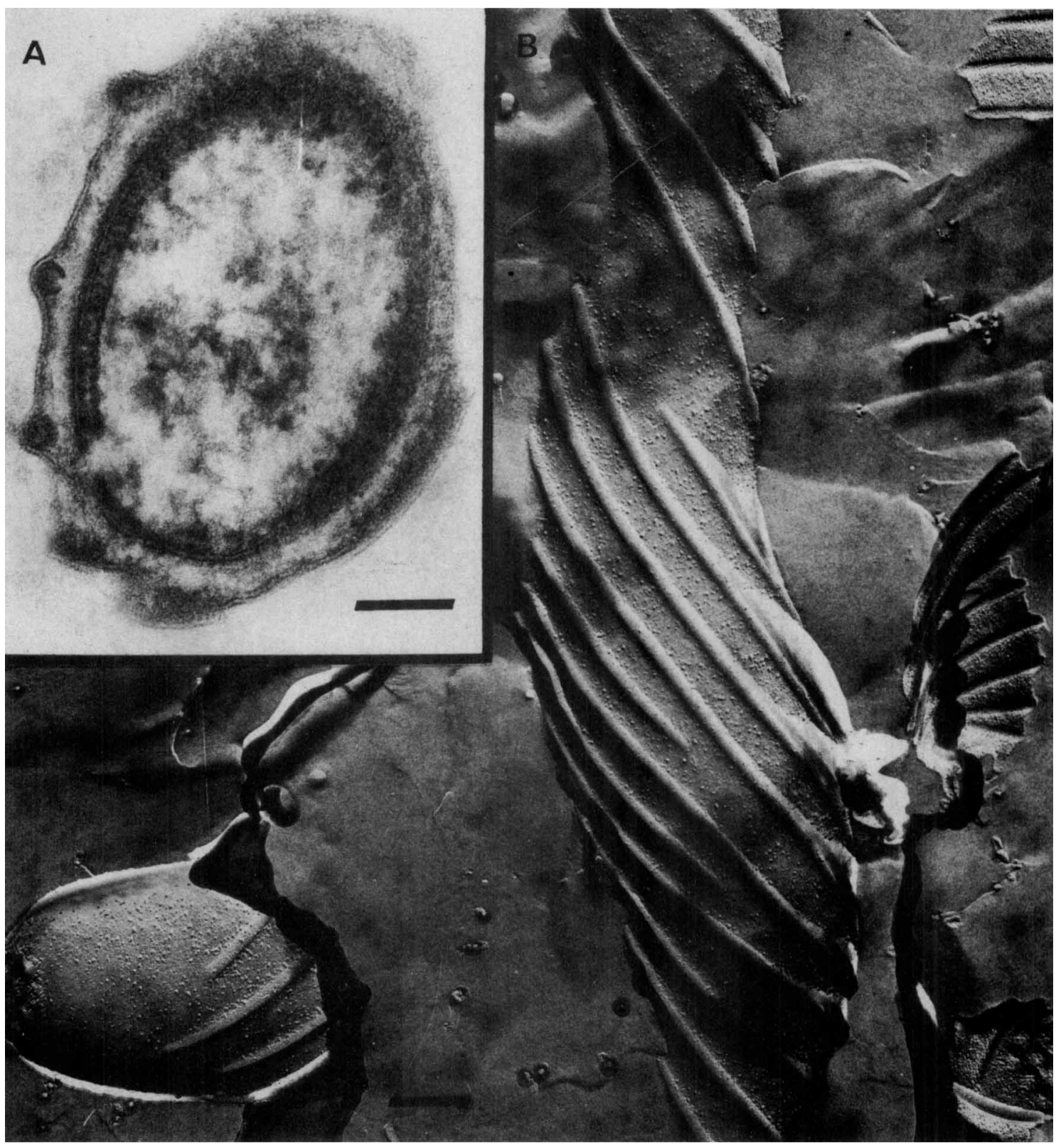

FIG. 2. Periplasmic fibers of $H$. muridarum sp. nov. (A) Transverse section of strain ST1 ${ }^{\mathrm{T}}$ showing circular, hollow periplasmic tubules. $\mathrm{Bar}=0.1 \mu \mathrm{m}$. (B) Freeze fracture preparation of strain $\mathrm{ST}^{\mathrm{T}}$ showing arrangement of periplasmic fibers. Bar $=0.2 \mu \mathrm{m}$.

Thin sections examined by transmission electron microscopy showed that the periplasmic fibers, which were cut at a variety of angles, were not solid filaments but were hollow tubules with a diameter of 28 to $32 \mathrm{~nm}$ (Fig. 2A). The thickness of the tubule wall was approximately $5 \mathrm{~nm}$. The fibers on the cell surface were coiled around the length of each organism. Observation of many preparations indicated that the arrangement of the periplasmic fibers was not constant; the spacing, distribution, and termination points of the ridges were variable (Fig. $2 \mathrm{~B}$ ).

Sections also revealed that the polar regions of the cells adjacent to the attachment sites of the flagella were electron translucent (Fig. 3A). Associated with each translucent region were electron-dense bands that lined the cytoplasmic membrane. These bands were 8 to $10 \mathrm{~nm}$ wide and $20 \mathrm{~nm}$ from the cytoplasmic membrane and contained striated material with a periodicity of $10 \mathrm{~nm}$ (Fig. $2 \mathrm{~A}$ and $3 \mathrm{~B}$ ).

The sheaths on the flagella were a continuation of the cell wall that was loosely arranged proximal to the protoplasmic cylinder, and they contained electron-dense cores having a maximum diameter of 12 to $13 \mathrm{~nm}$. Where the cores of the flagella entered the periplasm, there was a flat, electrondense band that was below the level of the cell wall and had a diameter of $40 \pm 4 \mathrm{~nm}$ (Fig. 3B).

Fractures through the polar region of the cells revealed more details of the components associated with insertion of the flagella. Characteristically, this region was free of ridges and was the site of variable numbers (average, 13 to 15) of 


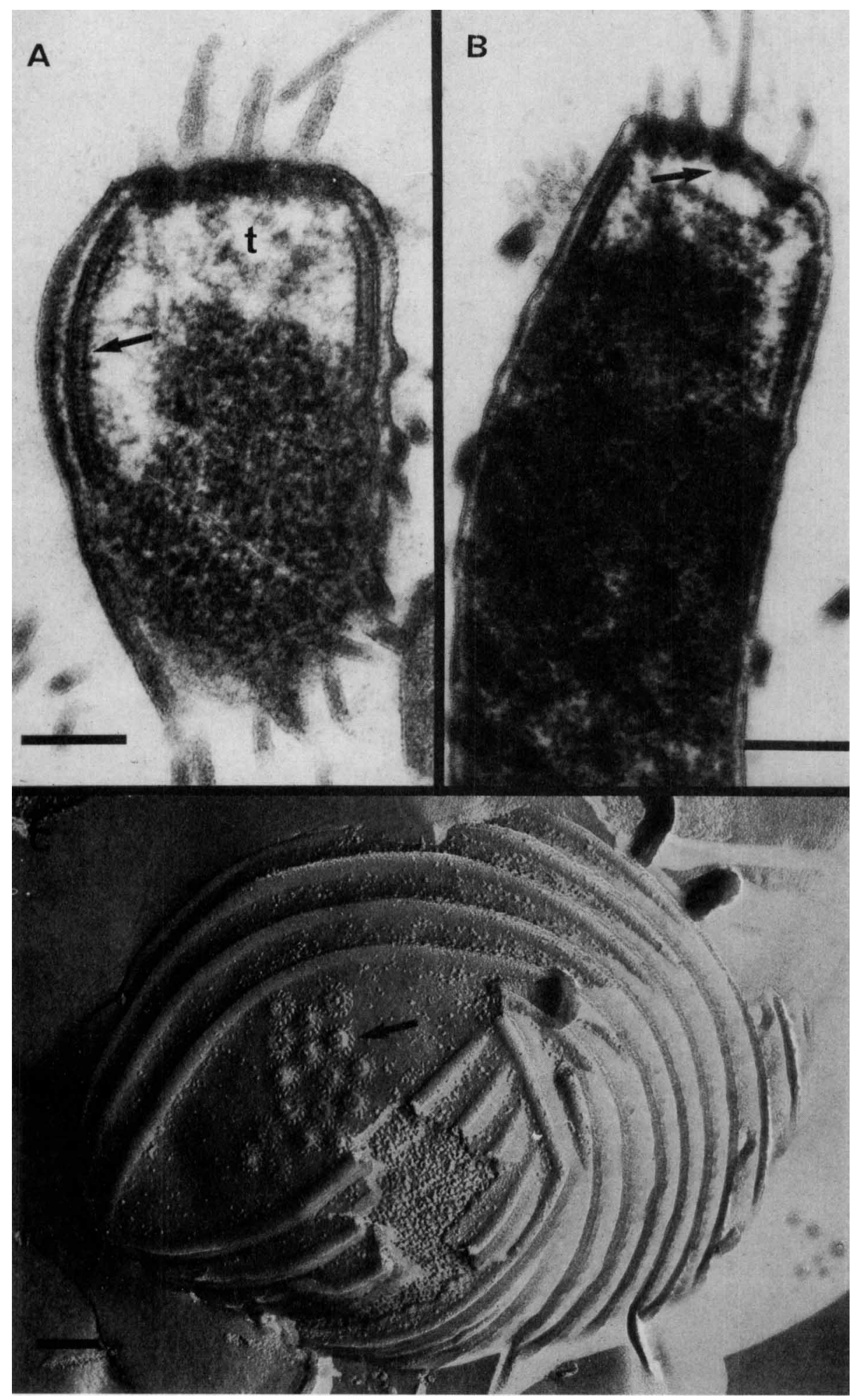

FIG. 3. Flagella of $H$. muridarum sp. nov. (A) Thin section of the polar region of strain $\mathrm{ST} 1^{\mathrm{T}}$ showing the electron-translucent region adjacent to the attachment sites of the flagella $(\mathrm{t})$ and the electron-dense bands lining the cytoplasmic membrane (arrow). Bar $=0.2 \mu \mathrm{m}$. $(\mathrm{B})$ Thin section of the polar region of strain $\mathrm{ST1}^{\mathrm{T}}$ showing the continuous nature of the cell wall and the sheath of the flagella and the electron-dense material below the insertion of the flagella (arrow). Bar $=0.2 \mu \mathrm{m}$. (C) Freeze fracture preparation of strain ST1 ${ }^{\mathrm{T}}$ showing the circular complexes (arrow) associated with the flagella. Bar $=0.2 \mu \mathrm{m}$. 
circular complexes (Fig. 3C). Each flagellum cleaved near the base appeared as a central circular component that was surrounded by 17 to 20 oval particles, each approximately 15 by $7 \mathrm{~nm}$; these particles occurred in a ring with a diameter of approximately $90 \mathrm{~nm}$.

Treatment with the detergent Teepol disrupted the outer membrane without destroying the periplasmic fibers or flagella. The periplasmic fibers unravelled from the protoplasmic cylinder (Fig. 4A), and we observed that they were not inserted into the protoplasmic cylinder at any point. There was no association between the fibers and the polar flagella, which confirmed previous observations. The ends of the fibers had no specialized structures or any internal core material and were of a constant diameter ( 28 to $30 \mathrm{~nm})$. At a higher magnification the fibers had a striated appearance and a periodicity of $9 \mathrm{~nm}$ (Fig. 4B).

Treatment with Teepol also led to breakdown of the sheath on the flagella, leaving a core that was $15 \mathrm{~nm}$ in diameter and remained inserted into the protoplasmic cylinder. By briefly sonicating Teepol-treated organisms for $15 \mathrm{~s}$, we ruptured the cytoplasmic membrane, revealing components that were associated with the insertion of the flagella. Many flagella were attached at one end to the center of a small circular body (Fig. 4C). Each circular body had three rings; one of these rings had a diameter of 16 to $20 \mathrm{~nm}$, another had a diameter of 42 to $47 \mathrm{~nm}$, and the external ring had a diameter of 68 to $72 \mathrm{~nm}$.

In older cultures there were many coccoid cells which, when examined by transmission electron microscopy, appeared to be degenerating helical cells. Two types of coccoid cells were observed, those with disrupted cytoplasmic membranes (Fig. 5A) and those with altered cell walls (Fig. 5B and $C$ ). Where the cytoplasmic membrane had ruptured, leaving only the outer membrane enclosing the cell contents, the cytoplasm filled the periplasm, swelling the surrounding cell wall. In organisms in which the peptidoglycan was degraded, the cytoplasm was contained in spheroplasts bounded by the outer and cytoplasmic membranes. Although periplasmic fibers were not detected on the altered cell walls, the ridges on the surface remained.

Biochemical and physiological characteristics. The biochemical and physiological characteristics of the five strains which we examined are shown in Table 1 together with the characteristics of the other Helicobacter species, Campylobacter jejuni, and Wolinella succinogenes.

Genetic relatedness. The nucleotide base composition of strain ST1 ${ }^{\mathrm{T}}$ DNA was $34.6 \pm 0.6 \mathrm{~mol} \% \mathrm{G}+\mathrm{C}$.

Approximately $95 \%$ (1,442 bases) of the total 16S rRNA sequence of $H$. muridarum $S T 1^{\mathrm{T}}$ was sequenced. This sequence was aligned in our data base, which consists of nearly complete $16 \mathrm{~S}$ rRNA sequences of more than 300 microorganisms. A similarity matrix was determined from a comparative analysis of the 16S rRNA sequences of strain $\mathrm{ST}^{\mathrm{T}}$, Helicobacter species, Campylobacter species, and other related bacteria. Figure 6 shows a phylogenetic tree which was constructed from the similarity data. As this dendrogram shows, strain $\mathrm{ST}^{\mathrm{T}}$ is clearly related to Helicobacter species (average level of similarity, approximately $94 \%)$.

\section{DISCUSSION}

The data described above confirm that the rodent isolates are members of a Helicobacter species and deserve a formal name. Previously, we speculated that the helicobacters are a group of related bacteria that have evolved such that they can survive in gastric environments. In contrast, the natural habitat of $H$. muridarum is the lower bowel, an observation which seems to conflict with the gastric hypothesis. However, we have shown that if conditions in the stomach are modified, $H$. muridarum can colonize gastric pits in large numbers (19a). The bacteria observed in the stomachs of BALB/c mice by Queiroz et al. (35) were probably $H$. muridarum.

As the genus Helicobacter expands, it is clear that it includes bacteria other than gastric colonizers. The rectal inhabitants Campylobacter cinaedi and Campylobacter fennelli have recently been classified as helicobacters (43). Furthermore, Campylobacter-like organisms isolated from the feces of wild birds were confirmed as a new Helicobacter species by using DNA probes and 16S rRNA sequencing (40).

A comparison between the gastric helicobacters and the new nongastric helicobacters should provide important information that is relevant to our understanding of gastroduodenal disease; i.e., we should be able to identify more features that are essential to survival in the stomach. In a comparative study in which we used $H$. pylori, $H$. felis, and $H$. muridarum we found that the urease of the gastric colonizers has two $\mathrm{pH}$ optima and that one of these optima is at an acid $\mathrm{pH}$, in contrast to $H$. muridarum, which has one $\mathrm{pH}$ optimum at a neutral $\mathrm{pH}$. We have proposed that urease activity at low $\mathrm{pH}$ values is essential for colonization of gastric mucosa (12)

$H$. muridarum has many ultrastructural features in common with other spiral bacteria. The insertion sites of the flagella resemble similar structures in $H$. felis (24), Aquaspirillum serpens (7), Spirillum voltans (42), and W. succinogenes (22). Furthermore, the insertion region contains features that closely resemble the cytoplasmic flagellum bases observed in $S$. volutans by Swan (42). The cytoplasm near the tip of each cell was found to be electron translucent, and a "polar membrane" similar to that described by Coulton and Murray for other polarly flagellated bacteria, including $C$. jejuni $(3,7)$, was found lining the cytoplasmic membrane in this region. An examination of negatively stained preparations of disrupted cells revealed circular, concentric ring structures, some of which were attached to flagella. These structures resembled the concentric membrane ring found in Vibrio cholerae and Campylobacter fetus (13). Freeze fractures of the polar cell wall regions revealed rings of intramembrane particles surrounding the core of the flagella, features also observed in $\mathrm{H}$. felis (24) and $A$. serpens (7). From an analysis of the information derived from negative staining, thin sectioning, and the freeze fracture technique, the observations described below were made. The dark band that was observed under the cell wall in thin sections was the same diameter $(70 \mathrm{~nm})$ as the circular rings observed in negatively stained preparations, while the central hole was the same width $(15 \mathrm{~nm})$ as the appendages in section. The ring of particles observed in the fracture preparations had a diameter similar to the diameter of the circular ring structures and lay immediately above these structures in the cell wall. Coulton and Murray (7) suggested that the most likely role for the concentric membrane ring in spirilla is to stabilize and reinforce the cell wall membrane against the force of the spinning flagella. Such a role could also be applicable to the spiral organisms, especially as the cell walls of these organisms do not enclose the basal complex as they do in bacteria with unsheathed flagella, such as $S$. serpens.

The periplasmic fibers of $H$. muridarum reveal an inter- 


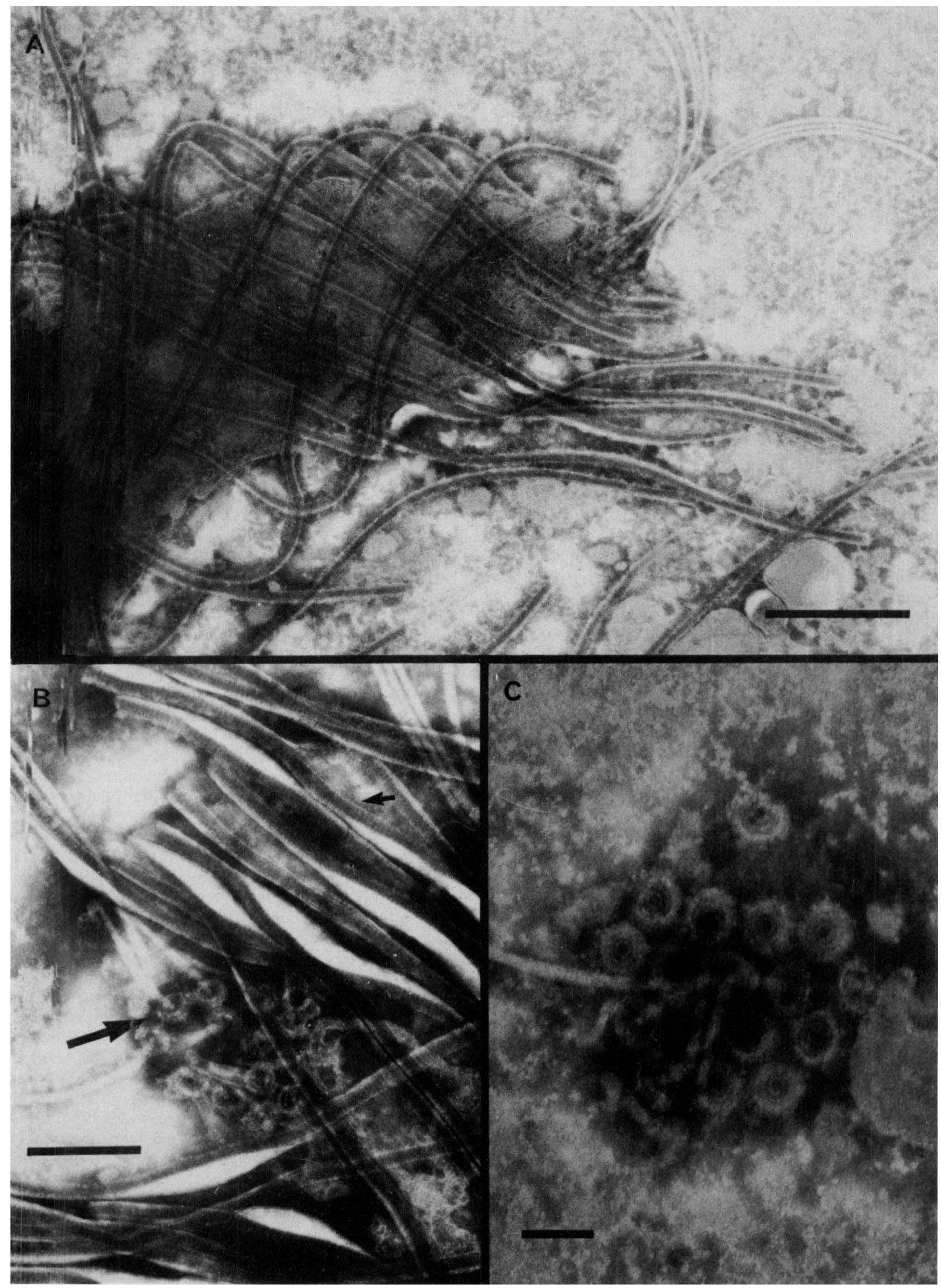

FIG. 4. Negatively stained preparations of strain $\mathrm{ST} 1^{\mathrm{T}}$ after treatment with Teepol. (A) Unravelling of periplasmic fibers showing that they were not inserted into the protoplasmic cylinder and their lack of association with the flagella. Bar $=0.5 \mu \mathrm{m}$. (B) Striated nature of the periplasmic fibers (small arrow) and circular bodies attached to the flagella (large arrow). Bar $=0.1 \mu \mathrm{m}$. (C) Higher magnification showing greater detail of the circular bodies attached to the flagella. Bar $=0.1 \mu \mathrm{m}$. 


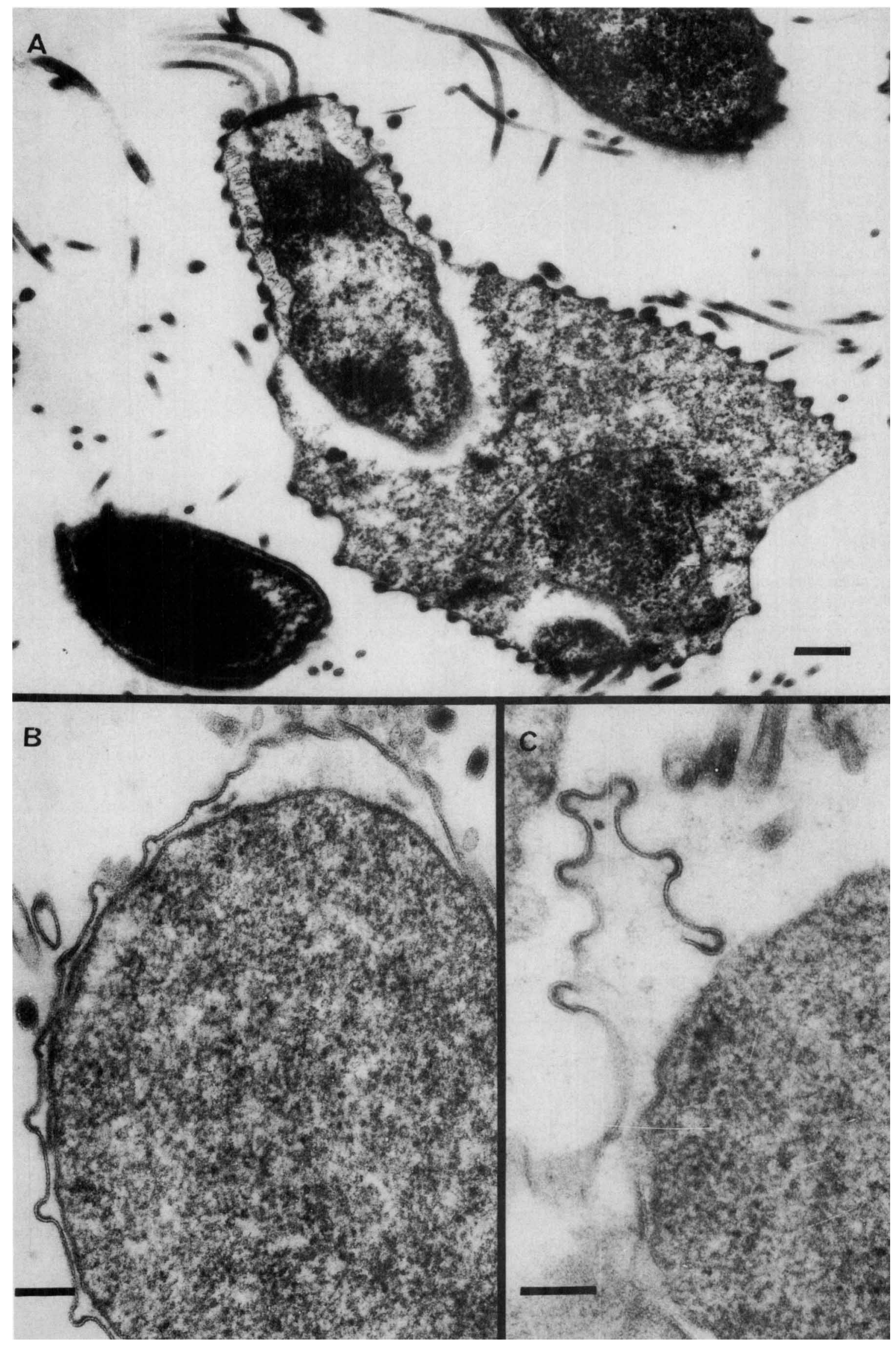

FIG. 5. Thin sections of older cultures of strain $\mathrm{STl}^{\mathrm{T}}$. (A) Coccoid cell with a disrupted cytoplasmic membrane. Bar $=0.2 \mu \mathrm{m}$. (B and C) Coccoid cells with disrupted cell walls. Bars $=0.1 \mu \mathrm{m}$. 
TABLE 1. Biochemical and physiological characteristics of $\boldsymbol{H}$. muridarum and related bacteria

\begin{tabular}{|c|c|c|c|c|c|c|}
\hline Characteristic & $\begin{array}{l}\text { H. muridarum } \\
\text { (five strains) }\end{array}$ & $\begin{array}{c}\text { H. pylori } \\
\text { NCTC } 11637\end{array}$ & $\begin{array}{l}\text { H. mustelae } \\
\text { ATCC } 43773\end{array}$ & $\begin{array}{l}\text { H. felis } \\
\text { ATCC } 49179\end{array}$ & $\begin{array}{l}\text { W. succinogenes } \\
\text { NCTC } 11488\end{array}$ & $\begin{array}{c}\text { C. jejuni } \\
\text { (two strains) }\end{array}$ \\
\hline Urease activity (rapid) & $+(5)^{a}$ & + & + & + & - & - \\
\hline Catalase activity & $+(5)$ & + & + & + & - & + \\
\hline Oxidase activity & $+(5)$ & + & + & + & + & + \\
\hline $\mathrm{H}_{2} \mathrm{~S}$ production & $-(5)$ & - & - & - & - & + \\
\hline $\mathrm{G}+\mathrm{C}$ content $(\mathrm{mol} \%)$ & 34.6 & 37 & 36 & 42.5 & 47 & $30-38$ \\
\hline Nitrate reduction & $-(5)$ & - & + & + & + & + \\
\hline Hippurate hydrolysis & $-(5)$ & - & - & - & - & + \\
\hline Alkaline phosphatase activity & $+(5)$ & + & + & + & - & - \\
\hline Arginine aminopeptidase activity & $+(5)$ & + & + & + & + & + \\
\hline Histidine aminopeptidase activity & $-(5)$ & + & + & + & - & - \\
\hline Leucine aminopeptidase activity & $+(4)$ & + & + & + & + & + \\
\hline Glutamyl transpeptidase activity & $+(5)$ & + & + & + & - & + \\
\hline \multicolumn{7}{|l|}{ Resistance to: } \\
\hline Nalidixic acid $(30-\mu \mathrm{g}$ disk) & $+(5)$ & + & - & + & + & - \\
\hline Cephalothin $(30-\mu \mathrm{g}$ disk $)$ & $+(5)$ & - & + & - & + & + \\
\hline \multicolumn{7}{|l|}{ Growth in the presence of: } \\
\hline $1 \%$ Glycine & - & - & - & - & $\mathrm{ND}^{b}$ & + \\
\hline $1.5 \% \mathrm{NaCl}$ & - & - & - & - & - & + \\
\hline \multicolumn{7}{|l|}{ Growth at: } \\
\hline $42^{\circ} \mathrm{C}$ & - & - & + & + & + or - & + \\
\hline $37^{\circ} \mathrm{C}$ & $+(5)$ & + & + & + & + & + \\
\hline $25^{\circ} \mathrm{C}$ & - & - & - & - & - & - \\
\hline \multicolumn{7}{|l|}{ Growth under: } \\
\hline Aerobic conditions & - & - & - & - & - & - \\
\hline Microaerophilic conditions & $+(5)$ & + & + & + & - & + \\
\hline Anaerobic conditions & - & + & + & + & + & + \\
\hline
\end{tabular}

${ }^{a}$ The numbers in parentheses are the numbers of strains that have the reactions indicated.

${ }^{b} \mathrm{ND}$, not determined.

esting ultrastructure. The striated structures shown in Fig. $4 \mathrm{~A}$ and $\mathrm{B}$ are reminiscent of myosin and thus are suggestive of a primitive contractile structure. The function of these fibers is unknown, but it is presumably related to the vigorous corkscrewlike motility of the bacteria. This could be active or passive as the ridges formed by the fibers could increase torque in viscous environments. Given that we have claimed that the spiral bacteria of gastrointestinal tracts have

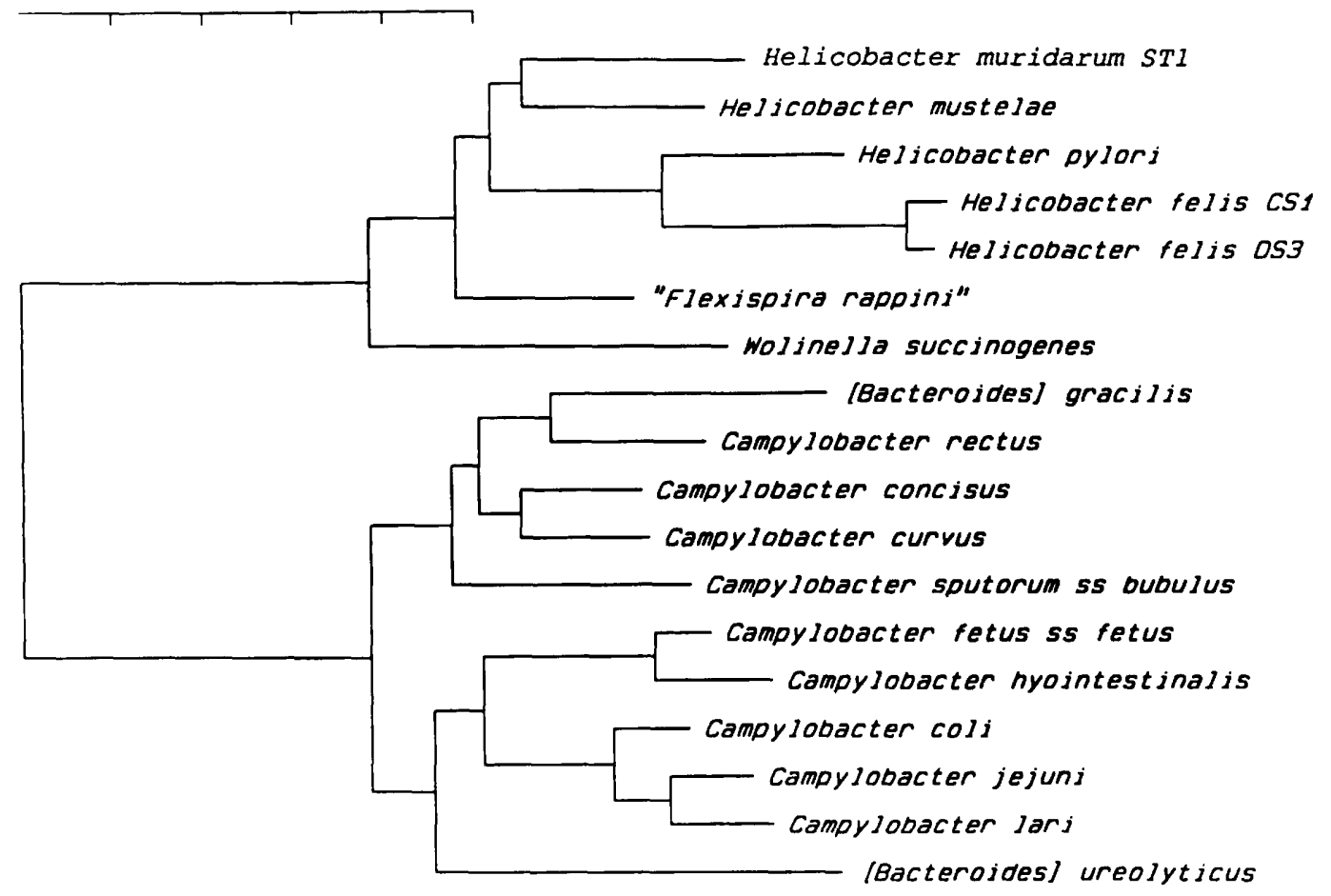

FIG. 6. Phylogenetic tree for the helicobacters, campylobacters, and related organisms. The scale bar represents a $5 \%$ difference in nucleotide sequences (determined by taking the sum of all of the horizontal lines connecting two species). Vertical distance has no meaning. 
evolved to survive best in a mucous environment (23), the study of the motility of the Helicobacter species which exhibit very distinct morphologies could be very revealing.

Physiologically, as Table 1 shows, the four species which we examined are very similar. Indeed, the only speciesspecific biochemical tests are the tests for histidine aminopeptidase (negative for $H$. muridarum) and resistance to nalidixic acid (negative for Helicobacter mustelae). As expected, the differences between $H$. muridarum and $W$. succinogenes and $C$. jejuni are marked.

The position of "Flexispira rappini" (4) still needs clarification, Goodwin (17) having stated that this organism is not a helicobacter. " $F$. rappini" certainly shares the morphological feature of multiple periplasmic fibers, but it does not have a helical morphology. We previously reported, on the basis of $16 \mathrm{~S}$ rRNA sequencing data, that this organism may represent a species of helicobacter (33), and this hypothesis is supported by our data, which showed that " $F$. rappini" and $H$. muridarum have a level of similarity of $96 \%$. Therefore, the positions of this bacterium and the organism that was described by Archer et al. $(1,36)$ as being associated with gastritis may become clearer as more Helicobacter species are described. The phylogenetic position of $W$. succinogenes still remains uncertain, although this organism is clearly related to the helicobacters.

Thus, the genus Helicobacter is expanding, with a number of possible new species waiting in the wings. Characterization of this group is important as it may identify unique properties that may be linked to pathogenecity. Accordingly, below we propose a name for the murine strains, which form a coherent group.

Description of Helicobacter muridarum sp. nov. Helicobacter muridarum (mu.ri.da'rum. $L$. $n$. Muridae, family name for Old World rats and mice; L. gen. n. muridarum, of the Muridae). Helical cells that are 0.5 to $0.6 \mu \mathrm{m}$ wide and 3.5 to $5.0 \mu \mathrm{m}$ long and have two to three spiral turns. Spherical forms 2 to $4 \mu \mathrm{m}$ in diameter are present in older cultures. Gram negative. No endospores are produced. Cells are motile with a rapid corkscrewlike motion. Cells have bipolar tufts of 10 to 14 sheathed flagella. Each cell is surrounded by 9 to 11 periplasmic fibers which appear as concentric helical ridges on the surface of the cell. Microaerophilic. Good growth occurs in atmospheres containing 1 to $16 \%$ oxygen and 5 to $10 \% \mathrm{CO}_{2}$. No growth occurs under aerobic or anaerobic conditions. Nutritionally fastidious, growing only on media enriched with blood or serum. Optimum growth occurs on a moist agar surface. Grows as a fine, translucent, spreading film on agar after 2 to 3 days. Growth occurs at $37^{\circ} \mathrm{C}$ but not at 25 or $42^{\circ} \mathrm{C}$. Viability is lost rapidly. No acid is produced from arabinose, cellobiose, galactose, glucose, glycerol, inositol, lactose, maltose, mannitol, raffinose, ribose, salicin, sorbitol, starch, sucrose, or xylose. Urease, oxidase, and catalase positive. Alkaline phosphatase and arginine aminopeptidase are produced. Lipase and lecithinase are not produced. Gelatin, casein, starch, tributyrin, and hippurate are not hydrolyzed. No production of $N$-acetyl-glucosaminidase, $\alpha$-glucosidase, $\alpha$-arabinosidase, $\beta$-glucosidase, $\alpha$-fucosidase, $\alpha$-galactosidase, $\beta$-galactosidase, leucine aminopeptidase, proline aminopeptidase, pyroglutamic acid arylamidase, tyrosine aminopeptidase, arginine aminopeptidase, alanine aminopeptidase, histidine aminopeptidase, phenylalanine aminopeptidase, or glycine aminopeptidase. Nitrate is not reduced. Indole and $\mathrm{H}_{2} \mathrm{~S}$ are not produced. No growth occurs in the presence of $2 \%$ bile salts, $1 \%$ glycine, or $1.5 \% \mathrm{NaCl}$. Resistant to nalidixic acid and cephalothin.
Isolated from the intestinal mucosa of the rats and mice. Type strain ST1 (= ATCC 49282) was isolated from a rat ileum, and its $\mathrm{G}+\mathrm{C}$ content is $34 \mathrm{~mol} \%$.

\section{ACKNOWLEDGMENTS}

We thank John Bowman and Vullapa Arunpairojana for assistance with DNA purification and analysis.

This work was supported in part by the National Health and Medical Research Council of Australia.

\section{REFERENCES}

1. Archer, J. R., S. Romero, A. E. Ritchie, M. E. Hamacher, B. M. Stenier, J. H. Bryner, and R. F. Schell. 1988. Characterization of an unclassified microaerophilic bacterium associated with gastroenteritis. J. Clin. Microbiol. 26:101-105.

2. Blackall, L. L., A. C. Hayward, and L. I. Sly. 1985. Cellulolytic and dextranolytic gram-negative bacteria: revival of the genus Cellvibrio. J. Appl. Bacteriol. 59:81-97.

3. Brock, F. M., and R. G. E. Murray. 1988. The ultrastructure and ATPase nature of polar membrane in Campylobacter jejeuni. Can. J. Microbiol. 34:594-604.

4. Bryner, J. H. 1988. Flexispira rappini, gen. nov., sp. nov. A motile, urease-producing rod similar to Campylobacter pyloridis, p. 440. In B. Kaijser and E. Falsen (ed.), Campylobacter IV. Goterna, Kungalv, Sweden.

5. Bryner, J. H., A. E. Ritchie, L. Pollet, A. Kirkbride, and J. E. Collins. 1987. Experimental infection and abortion of pregnant guinea pigs with a unique spirillum-like bacterium isolated from aborted ovine fetuses. Am. J. Vet. Res. 48:91-95.

6. Buck, G. E., W. K. Gourley, W. K. Lee, Subramanyam, J. M. Latimer, and A. R. DiNuzzo. 1986. Relation of Campylobacter pyloridis to gastritis and peptic ulcer. J. Infect. Dis. 15:664-669.

7. Coulton, J. W., and R. G. E. Murray. 1978. Cell envelope association of Aquaspirillum serpens flagella. J. Bacteriol. 135: 1037.

8. Davis, C. P., D. Mulcahy, A. Takeuchi and D. C. Savage. 1972. Location and description of spiral-shaped microorganisms in the normal rat cecum. Infect. Immun. 6:184-192.

9. Dent, J. C., C. A. M. McNulty, J. C. Uff, S. P. Wilkinson, and M. W. L. Gear. 1987. Spiral organisms in the gastric antrum. Lancet i:96.

10. Doenges, J. L. 1939. Spirochetes in the gastric glands of macacus rhesus and of man without related disease. Arch. Pathol. 25:469-477.

11. Erlandsen, S. L., and D. G. Chase. 1972. Paneth cell function: phagocytosis and intracellular digestion of intestinal microorganisms. II. Spiral microorganism. J. Ultrastruct. Res. 41:319 333.

12. Ferrero, R. L., and A. Lee. 1991. The importance of urease in acid protection for the gastric-colonising bacteria, Helicobacter pylori and Helicobacter felis sp. nov. Microbiol. Ecol. Health Dis. 4:121-134.

13. Ferris, F. G., T. J. Beveridge, M. L. Marceau-Day, and A. D. Larson. 1984. Structure and cell envelope associations of flagella basal complexes of Vibrio cholerae and Campylobacter fetus. Can. J. Microbiol. 30:322-333.

14. Fox, J. G., T. Chilvers, C. S. Goodwin, N. S. Taylor, P. Edmonds, L. I. Sly, and D. J. Brenner. 1989. Campylobacter mustelae, a new species resulting from the elevation of Campylobacter pylori subsp. mustelae to species status. Int. J. Syst. Bacteriol. 39:301-303.

15. Fox, J. G., B. M. Edrise, E. B. Cabot, C. Beaucage, J. C. Murphy, and K. S. Prostak. 1986. Campylobacter-like organisms isolated from the gastric mucosa of ferrets. Am. J. Vet. Res. 47:236-239.

16. Fox, J. G., B. P. Paster, A. Lee, F. E. Dewhirst, and N. S. Taylor. 1990. Genus and species probes for identification of Helicobacter sp. from man and animals. Third Workshop of the European Helicobacter pylori Study Group. Rev. Esp. Inf. Dig (Suppl. 1) 78:30-31.

17. Goodwin, C. S., J. A. Armstrong, T. Chilvers, M. Peters, M. D. Collins, L. Sly, W. McConnell, and W. E. S. Harper. 1989. 
Transfer of Campylobacter pylori and Campylobacter mustelae to Helicobacter pylori gen. nov. and Helicobacter mustelae comb. nov., respectively. Int. J. Syst. Bacteriol. 39:397-405.

18. Goodwin, C. S., J. A. Armstrong, and B. J. Marshall. 1986. Campylobacter pyloridis, gastritis and peptic ulceration. J. Clin. Pathol. 39:353-365.

19. Goodwin, C. S., R. K. McCulloch, J. A. Armstrong, and S. H. Wee. 1985. Unusual cellular fatty acids and distinctive ultrastructure in a new spiral bacterium (Campylobacter pyloridis) from the human gastric mucosa. J. Med. Microbiol. 19:257-267.

19a. Heneine, N., and A. Lee. Unpublished data.

20. Henry, G. A., P. H. Long, J. L. Burns, and D. L. Charbonneau. 1987. Gastric spirillosis in beagles. Am. J. Vet. Res. 48:831-836.

21. Kirkbride, C. A., C. E. Gates, J. E. Collins, and A. E. Ritchie. 1985. Ovine abortion associated with an anaerobic bacterium. J. Am. Vet. Med. Assoc. 186:789-791.

22. Kupper, J., I. Wildhaber, Z. Gao, and E. Baeverlin. 1989. Basal-body-associated disks are additional structural elements of the flagellum apparatus isolated from Wolinella succinogenes. J. Bacteriol. 171:2803-2810.

23. Lee, A. 1984. Neglected niches. The microbial ecology of the gastrointestinal tract. Adv. Microb. Ecol. 8:115-162.

24. Lee, A., S. L. Hazell, J. L. O'Rourke, and S. Kouprach. 1988. Isolation of a spiral shaped bacterium from the cat stomach. Infect. Immun. 56:2843-2850.

25. Lim, R. K. S. 1920. A parasitic spiral organism in the stomach of the cat. Parasitology 12:108-113.

26. Lockard, V. G., and R. K. Boler. 1970. Ultrastructure of a spiraled microorganism in the gastric mucosa of dogs. Am. J. Vet. Res. 31:1453-1462.

27. Marmur, J. 1961. A procedure for the isolation of deoxyribonucleic acid from micro-organisms. J. Mol. Biol. 3:208-218.

28. Marshall, B. J. 1986. Campylobacter pyloridis and gastritis. J. Infect. Dis. 153:650-657.

29. Marshall, B. J., D. B. McGechie, P. A. Rogers, and R. J. Glancy. 1985. Pyloric campylobacter infection and gastroduodenal disease. Med. J. Aust. 142:439-444.

30. Marshall, B. J., H. Royce, D. I. Annear, C. S. Goodwin, J. W. Pearman, J. R. Warren, and J. A. Armstrong. 1984. Original isolation of Campylobacter pyloridis from human gastric mucosa. Microbios Lett. 25:83-88.

31. O'Rourke, J. L., A. Lee, and J. G. Fox. An ultrastructural study of Helicobacter mustelae: evidence of a specific association with gastric mucosa. J. Med. Microbiol., in press.

32. Paster, B. J., and F. E. Dewhirst. 1988. Phylogeny of campylobacters, wolinellas, Bacteroides gracilis, and Bacteroides ure- olyticus by $16 \mathrm{~S}$ ribosomal ribonucleic acid sequencing. Int. J. Syst. Bacteriol. 38:56-62.

33. Paster, B. P., A. Lee, J. G. Fox, F. E. Dewhirst, L. A. Tordoff, J. G. Fraser, J. L. O'Rourke, N. S. Taylor, and R. Ferrero. 1991 Phylogeny of Helicobacter felis sp. nov., Helicobacter mustelae, and related bacteria. Int. J. Syst Bacteriol. 41:31-38.

34. Phillips, M. W., and A. Lee. 1983. Isolation and characterization of a spiral bacterium from the crypts of rodent gastrointestinal tracts. Appl. Environ. Microbiol. 45:675-683.

35. Queiroz, D. M. M., C. Contigli, R. S. Comibra, A. M. M. F. Nogueira, E. N. Mendes, G. A. Rocha, and R. J. A. Silva. 1990. Mice stomach naturally colonised by a spiral bacterium. Third Workshop of the European Helicobacter pylori Study Group. Rev. Esp. Inf. Dig. (Suppl. 1) 78:52-53.

36. Romaniuk, P. J., B. Zoltowska, T. J. Trust, D. J. Lane, G. J. Olsen, N. R. Pace, and D. A. Stahl. 1987. Campylobacter pylori, the spiral bacterium associated with human gastritis, is not a true Campylobacter sp. J. Bacteriol. 169:2137-2141.

37. Romero, S., J. R. Archer, M. E. Hamacher, S. M. Bologna, and R. F. Schell. 1988. Case report of an unclassified microaerophilic bacterium associated with gastroenteritis. J. Clin. Microbiol. 26:142-143.

38. Saitou, N., and M. Nei. 1987. The neighbour-joining method: a new method for reconstructing phylogenetic trees. Mol. Biol Evol. 4:406-425.

39. Savage, D. C., J. S. McAllister, and C. P. Davies. 1971. Anaerobic bacteria on the mucosal epithelium of the murine large bowel. Infect. Immun. 4:492-502.

40. Seymour, C., M. Kim, B. J. Paster, F. E. Dewhirst, and J. G. Fox. 1991. Helicobacter, Campylobacter, Yersinia, Budvicia, and Giardia from mammal and bird feces, p. 324. Abstr. 91s Gen. Meet. Am. Soc. Microbiol. 1991. American Society for Microbiology, Washington, D.C.

41. Sly, L. I., L. L. Blackall, P. C. Kraat, T.-S. Tao, and V. Sangkhobol. 1986. The use of second derivative plots for the determination of mol\% guanine plus cytosine of DNA by the thermal denaturation method. J. Microbiol. Methods 5:139-156.

42. Swan, M. A. 1985. Electron microscopic observations of structures associated with the flagella of Spirillum volutans. J. Bacteriol. 161:1137-1145.

43. Vandamme, P., E. Falsen, R. Rossau, B. Hosie, P. Segers, R. Tytgat, and J. De Ley. 1991. Revision of Campylobacter, Helicobacter, and Wolinella taxonomy: emendation of generic descriptions and proposal of Arcobacter gen. nov. Int. J. Syst Bacteriol. 41:88-103. 